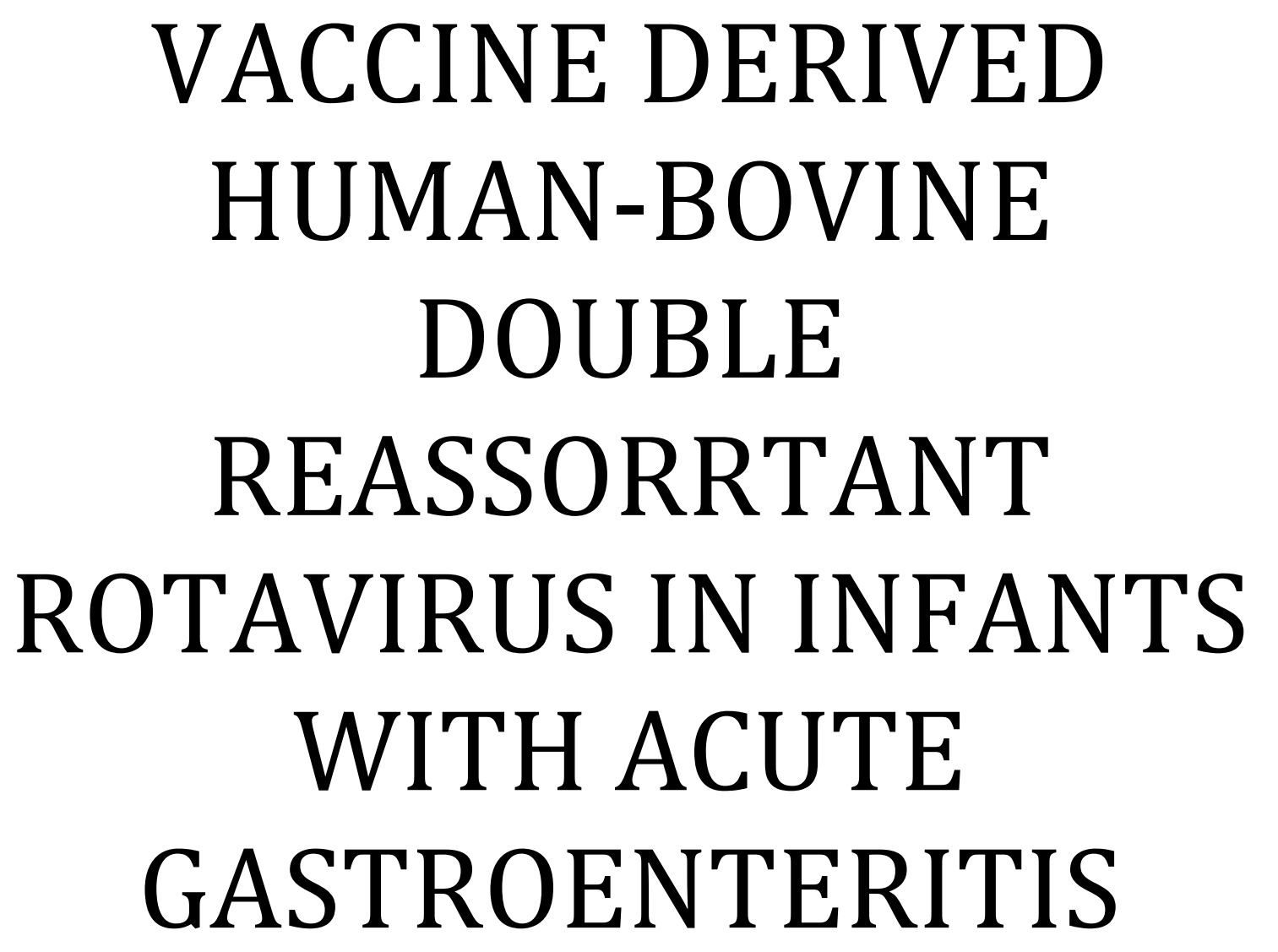

\title{
Syventävät opinnot
}

\section{Maria Hemming}

$9 / 1 / 2012$

We describe three cases of acute gastroenteritis in healthy infants after vaccination with

RotaTeq vaccine, shedding a G1P[8] human-bovine double reassortant rotavirus in stools. Such a double reassortant virus appears stable in vitro and may explain diarrheal symptpms in a small percentage of RotaTeq recipients, and might also be transmitted to contacts in the environment. 
Suomenkielinen tiivistelmä:

Rotavirukset ovat maailmanlaajuisesti yleisin pienten lasten vakavien ripulitautien aiheuttaja. Ennen rotavirusrokotuksia lasten rotavirusinfektiot aiheuttivat vuosittain kymmeniätuhansia sairaala- ja poliklinikkakäyntejä pienillä lapsilla. RotaTeq ${ }^{\circledR}$ rokote lisättiin Suomen kansalliseen rokotusohjelmaan syyskuussa 2009, kun se oli massiivisten tutkimusten jälkeen todettu turvalliseksi ja tehokkaaksi rokotteeksi rotavirus tautia vastaan. RotaTeq ${ }^{\circledR}$ on elävä, heikennetty rokote, joka sisältää viittä inmisen ja naudan yhdistelmävirusta. Yhdistelmäviruksissa toinen ulommista pintaproteiineista, VP7 tai VP4, on inmisperäinen ja toinen nautaperäinen. Suomessa immunisointi tapahtuu 2, 3 ja 5 kuukauden ikäisenä.

Tutkimuksen tarkoituksena oli selvittää Tampereen yliopistollisessa sairaalassa (TAYS) syyskuun 2009 ja elokuun 2011 välillä hoidettujen oksennus- ja/tai ripulitautia sairastavien lasten pääasiallisia taudinaiheuttajia. Tutkimukseen osallistuneilta lapsilta kerättiin ulostenäyte, josta tutkittiin rotaviruksen lisäksi norovirus, adenovirus, coronavirus sekä bocavirus PCR- menetelmillä. Rotavirus positiivisista näytteistä selvitettiin lisäksi viruksen uloimman kerroksen kahden pintaproteiinin, VP7 ja VP4 genomi viruksen tyypitystä varten, sekä keskikerroksen proteiinin VP6 sekvenssi mahdollisen rokoteviruksen tunnistamiseksi.

Tutkimuksessa löydettiin 3 lasta, joilla oksennus-ja/tai ripulitaudin aiheuttaja oli rokotteesta peräisin oleva uusi yhdistelmävirus. Uudessa rokoteperäisessä viruksessa kaksi RotaTeq ${ }^{\circledR}$ rokotteen virusta ovat yhdistyneet siten, että muodostuneen uuden yhdistelmäviruksen uloimman kerroksen kumpikin proteiini, VP7 ja VP4, ovat inmisperäisiä. Merkittävänä tutkimustuloksena selvisi, että uusi rokoteperäinen yhdistelmävirus on infektiivinen ja stabiili. Se voi aiheuttaa oksennus-ja/tai ripulitaudin oireita rokotetuilla lapsilla, jotka voivat erittää virusta edelleen ympäristöönsä. 


\section{INTRODUCTION}

RotaTeq ${ }^{\circledR}(R V 5$, Merck\&Co. Inc., in Europe SanofiPasteur-MSD) is an oral liveattenuated human-bovine reassortant vaccine that contains five reassortants on bovine G6P[5] rotavirus backbone, four of which express the human VP7 antigen G1,G2,G3 or G4, respectively. One reassortant expresses human VP4 P1A[8] and retains VP7 type G6 from the bovine rotavirus parent strain WC3. ${ }^{1-3}$

RotaTeq ${ }^{\circledR}$ was licenced in 2006 following a large trial called REST (RotaTeq Efficacy and Safety Trial), involving 70,000 infants. ${ }^{1}$ In the US, the incorporation of RotaTeq ${ }^{\circledR}$ into routine immunization program has been highly successful in preventing hospitalizations and emergency department visits due to wild-type rotavirus gastroenteritis. ${ }^{4-6}$ Rotavirus vaccination was introduced into the Finnish National Immunization Program as of September 1, 2009, and RotaTeq ${ }^{\circledR}$ has been exclusively used in Finland since then. In Finland, RotaTeq ${ }^{\circledR}$ is given in three doses at ages 2, 3 and 5 months. The vaccination coverage is about $96 \%$, or approximately 56,000 vaccinated children annually (Source: National Institute of Health and Welfare (THL), Finland).

RotaTeq ${ }^{\circledR}$ is generally regarded as a very safe vaccine. However, a small increase in diarrhea and vomiting in the first week after the first dose has been observed in large materials. ${ }^{2,3}$ Recently, diarrhea in children after RotaTeq ${ }^{\circledR}$ vaccination was reported from the $\mathrm{US}^{7,8}$ and Australia.(Kirkwood CD, Donato $\mathrm{C}$, Ch'ng LS, et al. Identification of RotaTeq ${ }^{\circledR}$ vaccine in paediatric patients with 
acute gastroenteritis following routine vaccination. In: Vaccines for Enteric Diseases, Cannes, France, 2011. Poster presentation) The diarrhea was associated with the formation of a new human-bovine double reassortant between G1P[5] and G6P[8] strains from the pentavalent vaccine. ${ }^{8}$ We describe three cases of acute gastroenteritis after RotaTeq ${ }^{\circledR}$ vaccination in healthy infants, all of whom shed such a G1P[8] double reassortant in the absence of other viral pathogens.

\section{METHODS}

A prospective study on the etiology of acute gastroenteritis (AGE) in children started on 1 September 2009 in Tampere University Hospital concurrently with the introduction of RotaTeq ${ }^{\circledR}$ vaccine and was conducted until 31 August 2011. The study was approved by The Ethics Committee of Pirkanmaa Hospital District. Patients with AGE less than 16 years of age, who were seen in the emergency department (ED) of the hospital or were admitted to a pediatric ward, were eligible for the study, subject to obtaining informed consent from the parents.

Stool specimens were collected from 316 patients and examined at the Vaccine Research Center of the University of Tampere Medical School. The stools were collected in the outpatient clinic or, if the patient was hospitalized, in the ward, 
and studied by reverse transcription-polymerase chain reaction (RT-PCR) methods for several gastroenteritis viruses, including rotavirus. Of all enrolled subjects 79 (25\%) were rotavirus positive and of these 17 had received at least one dose of RotaTeq ${ }^{\circledR}$ vaccine. Rotavirus $\mathrm{G}$ and $\mathrm{P}$ genotypes were determined by nucleotide sequencing of the gene segments encoding for the VP7 and VP4 antigens ${ }^{9}$, respectively, and of the gene segment encoding for VP6 to determine the presence of vaccine derived virus.

For the VP6 RT-PCR, a method was kindly provided by Max Ciarlet, based on the method described by Iturriza-Gómara et $\mathrm{al}^{10}$, and adapted at Merck, Research Laboratories.

Briefly, the $379 \mathrm{bp}$ amplicons of the VP6 genes were obtained using primers Rota VP6-Fs (forward primer): 5'GAYGGNGCDACNACATGGT3' (nt 747-765) and Rota VP6-Rs (reverse primer): 5'GTCCARTTCATNCCTGGYGG3' (nt 11071126) synthesized in Sigma-Genosys $L t d$. . For $Y(C, T), R(A, G), D(A, G, T)$ and $N(A, G, C, T)$. The oligonucleotides were designed based on the sequence of the Wa (human) VP6 (Access no; K02086) and WC3 (bovine) VP6 (Access no; AF411322) genes.

The RT-PCR primers were further used as sequencing primers. Gel purified amplicons (QIAquick Gel Extraction Kit, Qiagen) were sequenced using BigDye Terminator v1.1 Cycle Sequencing v1.1 Ready Reaction Kit with AmpliTaq DNA Polymerase FS (Applied Biosystems) on an ABI Prism 310 Genetic Analyzer. 
Nucleotide sequences read from the chromatograms were aligned to published sequences from GenBank.

Stool specimens from patients who had received RotaTeq ${ }^{\circledR}$ vaccine were also tested for presence of rotavirus antigen by ELISA, using the IDEIA Rotavirus Kit (Oxoid Ltd, UK). The rotavirus ELISA positive stool specimen from Patient 3 was propagated in MA104 cells as described previously. ${ }^{11}$ For other gastroenteritis viruses, norovirus, sapovirus and bocavirus were tested as described previously. ${ }^{12,13}$ Coronavirus was tested as described by Risku et al. (Human bocavirus types 1, 2 and 3 in acute gastroenteritis of childhood. Paper submitted to Acta Pediatrica).

\section{CASE REPORTS}

\section{Patient 1}

A two-month-old girl had received the first dose of RotaTeq® vaccine in March 2010, 7 days before the onset of diarrhea. She was taken to the ED on the third day of illness after she had had diarrhea for two days (day 1: 15 loose stools, day 2: 5 loose stools). In the ED, she was pale and sleepy, had blood in her stools, and a rectal temperature of $37.8^{\circ} \mathrm{C}$. The extremities were warm, the mouth and tongue were moist, but she refused to drink. The estimated dehydration rate was $1-2 \%$. The patient was rehydrated with an oral rehydration solution and discharged, but at home the diarrhea continued for another 5 days. 
The infant had reached full gestational age but had had cardiac surgery one week after birth due to tetralogy of Fallot. She was growing and developing well, was breastfed, and, except for the follow-up of the heart surgery, did not have any hospitalizations or diseases.

\section{Patient 2}

A three-month-old boy had received the second dose of RotaTeq ${ }^{\circledR}$ vaccine in April 2011, one day before the onset of diarrhea. He was taken to the ED on the eighth day of illness when his general condition was getting worse. The infant had approximately 10 loose stools of greenish or yellowish colour per day. On admission he had a rectal temperature of $37.3^{\circ} \mathrm{C}$, the abdomen was tender, and there was slight reddish rash on the abdomen. He had instant recoil on skin turgor test, and his general condition was good. He had no breastfeeding problem and was discharged.

The infant had had no side effects after the first dose of RotaTeq ${ }^{\circledR}$ vaccine. He was born in the $37^{\text {th }}$ week and was growing and developing normally. Concomitantly with the second dose of RotaTeq ${ }^{\circledR}$, he had received Infanrix Penta (GSK) vaccine containing the diphtheria, tetanus, pertussis, Haemophilus influenzae type b (Hib) and inactivated polio virus (IPV) components.

\section{Patient 3}

A two-month-old girl had received the first dose of RotaTeq ${ }^{\circledR}$ vaccine in August 2011, five days before she was taken to the ED. Before admission, she had had 
vomiting for one day, diarrhea with a maximum of 12 loose stools a day and a rectal temperature up to $38.1^{\circ} \mathrm{C}$. On admission, she had a moist mouth and tongue and instant recoil on skin turgor test, but a sunken fontanel. The infant was irritable and due to vomiting had problems with breastfeeding; therefore overnight admission was required. She was discharged the next day, still having a temperature of $37.8^{\prime} \mathrm{C}$ but no diarrhea or vomiting. The fecal specimen was collected on the second day in hospital.

The infant was full term, was growing and developing normally, and had no previous medications, diseases or hospitalizations.

\section{Other Cases}

The same G1P[8] double reassortant human-bovine rotavirus as in patients 1-3 was also found from a three-month-old girl who had received her second dose of RotaTeq ${ }^{\circledR} 16$ days before hospital admission because of gastroenteritis. In this case norovirus was detected in the same stool specimen, and it was assumed that the principal cause of gastroenteritis symptoms was norovirus, which had infected all family members earlier the same week.

Additionally, one gastroenteritis patient was found to shed a single reassortant vaccine virus G6P[8]. This two-month-old boy had received the first dose of RotaTeq ${ }^{\circledR}$ vaccine five days before he was taken to the ED due to forceful vomiting. Even though the vomiting had started only one day before, an overnight admission was required and the infant was rehydrated with an oral rehydration 
solution before discharge. In the hospital the child had no fever or diarrhea. Tests for other gastroenteritis viruses were negative.

In the same study material, we also detected 8 patients who had received RotaTeq ${ }^{\circledR}$ and were shedding the G1P[5]-vaccine strain. All these patients had simultaneously other gastroenteritis viruses in their stools. Four of these patients shed the vaccine virus identical to the G1P[5]-strain. In the other cases, the VP4 was either negative in RT-PCR or two VP4 strains were detected by sequencing. The detection of two VP4s would indicate the presence of more than one vaccine virus, most likely G1P[5] and G6P[8] reassortants separately.

\section{LABORATORY FINDINGS}

In patients 1 through 3 , only one rotavirus was identified in the stool specimens by RT-PCR. In each case, the virus was a bovine rotavirus as determined by VP6 sequencing. Genotyping by RT-PCR confirmed that in each case the G-type was $\mathrm{G} 1$ and P-type was P[8].

In all three specimens, analysis of nucleotide sequences revealed that a 860base pair (bp) fragment of the VP7 gene and a 570 bp fragment of the VP4 gene were $100 \%$ identical to cognate gene segments from the corresponding G1P[5] and G6P[8] viruses in RotaTeq ${ }^{\circledR}$. Also, in all specimens, a 362bp fragment of VP6 gene segment was $100 \%$ identical to the WC3 cognate gene of RotaTeq ${ }^{\circledR}$. 
Neither RT-PCR nor sequencing detected any other rotavirus types in the stool specimens of these three patients.

The stool specimen from Patient 3 was ELISA positive, with an optical density (OD) of 0.910 (Rotaclone-positive OD>0.15). For Patients 1 and 2 ELISA tests were negative. The ELISA positive stool specimen from Patient 3 could be propagated in MA104 cells. Upon five passages the virus remained stable as a double reassortant and the sequencing of VP7, VP4 and VP6 were identical to the original isolate.

Other viral agents that were studied were norovirus, sapovirus, bocavirus and coronavirus. In the 3 cases, all tests for these viruses were negative.

\section{DISCUSSION}

We describe three patients with symptomatic gastroenteritis associated with vaccine-derived new G1P[8] human-bovine double reassortant rotavirus. This is a small number compared to the estimated 8000 infants that had received RotaTeq ${ }^{\circledR}$ vaccine in the 2 year period $2009-2011$ in the coverage area of Tampere University Hospital. This was $3.8 \%$ of the 79 rotavirus positive cases of acute gastroenteritis detected during the two-year period. On the other hand, it is possible that the true rate of symptomatic gastroenteritis, and, probably, asymptomatic shedding, due to vaccine-derived double reassortant may be higher, since mild cases of gastroenteritis associated with vaccination, and much less asymptomatic shedding, would not be detected in a hospital based survey. 
Wild-type rotavirus infects the mature enterocytes, and rotavirus may replicate for up to two weeks in the cells. ${ }^{14,15}$ For a double reassortant to develop, G1P[5] and G6P[8] reassortants would have to infect the same cell. Apparently this can happen in rare cases. ${ }^{7,8,16}$ It is of interest that all our cases as well as those reported previously are reassortants with G1 and not with other human G-types. G1 appears to be shed more commonly after vaccination than other G-types, ${ }^{17}$ and may therefore be more fit for multiplication. While the formation of a double reassortant between $\mathrm{G} 1$ and $\mathrm{P}[8]$ is more likely than other combinations it is not clear why a double reassortant G1P[8] should have greater virulence resulting in clinical symptoms.

Two cases happened after the administration of the first dose of RotaTeq ${ }^{\circledR}$. It is likely that multiplication of vaccine virus in the intestinal enterocytes is more effective after the first dose, possibly giving a greater chance of formation of new reassortants. Patient 2 had mild symptoms of gastroenteritis after the second dose. In this case it is possible that the first dose of RotaTeq $®$ had not taken, perhaps due to presence of maternally acquired antibodies, and the second dose was effectively the first successful vaccination for this infant. ${ }^{18,19}$

Our studies of viral culture showed that G1P[8] double reassortant appears stable in vitro. In the US, sibling transmission of vaccine-derived G1P[8] virus between an immunocompetent vaccinated sibling and a healthy 
immunocompetent unvaccinated sibling has already been reported. ${ }^{8}$ It is not known, but plausible, that the double reassortant could remain in circulation even longer than one transmission cycle. As immunocompromised people may continue to shed the wild-type rotavirus and the vaccine-acquired rotavirus in their stools for several months, the prolonged replication increases the probability of adverse events and the possibility of infecting contacts. ${ }^{7}$

Altogether, shedding of RotaTeq ${ }^{\circledR}$ vaccine virus in immunocompetent children appears to be more common than initially reported. In the REST study shedding was evaluated by viral culture with use of a plaque assay and RNA electropherotyping, ${ }^{1}$ which are relatively insensitive methods for detection of the vaccine virus. Other studies using ELISA, have revealed a shedding rate of $21.4 \%(22 / 103)$ in full term infants and $53 \%(8 / 15)$ in premature infants. ${ }^{20,21}$ None of these studies detected any double reassortant viruses.

Apart from the 3 cases with the double reassortant, we also saw one infant with symptomatic gastroenteritis shedding the original G6P[8] single reassortant vaccine virus. This raises the possibility that $P[8]$ alone may be associated with symptoms and might also be the component resulting in increased virulence of the double reassortant. When RotaTeq ${ }^{\circledR}$ was being developed, a study was conducted to compare the pentavalent composition, quadrivalent (G1, G2, G3 and G4) composition and monovalent (P1A[8]) composition. ${ }^{22}$ The results showed that the frequency of fever was higher after the first vaccination with 
pentavalent vaccine than with the quadrivalent composition group, suggesting a role in virulence of $\mathrm{P}[8]$.

Taken together, we propose that to induce diarrhea the VP4- protein from human origin has to be present in the vaccine virus, either as the new double reassortant G1P[8] or, perhaps, only as the original vaccine virus G6P[8].

\section{CONCLUSION}

Formation of G1P[8] double reassortants may explain diarrheal symptoms in a small percentage of RotaTeq ${ }^{\circledR}$ recipients. The reassortment between two vaccine strains may occur during intestinal replication even in immunocompetent infants. Such a double reassortant virus appears stable and might also be transmitted to contacts in the environment.

\section{ACKNOWLEDGEMENT}

The authors thank Marjo Salonen, RN, for collecting patient data, and Eeva Jokela, Sanna Kavén, Nina Koivisto and Emilia Halttunen for laboratory assistance.

We are grateful to Marjo Salminen, Engineer, and Suvi Lappalainen, M.Sc., for their expertise and help with the study. 


\section{REFERENCES}

1. Vesikari T, Matson DO, Dennehy P, et al. Safety and efficacy of a pentavalent human-bovine (WC3) reassortant rotavirus vaccine. N Engl J Med. 2006;354:2333.

2. Heaton PM, Ciarlet M. The pentavalent vaccine: discovery to licensure and beyond. Clin Infect Dis. 2007;45:1618-24

3. Ciarlet M, Schodel F. Development of a rotavirus vaccine: clinical safety, immunogenicity, and efficacy of the pentavalent rotavirus vaccine, RotaTeq. Vaccine. 2009;27 Suppl 6:G72-81.

4. Boom JA, Tate JE, Sahri LC, et al. Effectiveness of pentavalent rotavirus vaccine in a large urban population in the United States. Pediatrics. 2010;125:e199-207.

5. Tate JE, Cortese MM, Payne DC, et al. Uptake impact and effectiveness of rotavirus vaccination in the United States: review of the first 3 years of postlicensure data. Pediatr Infect Dis J. 2011;30 (1 Suppl) :S56-60

6. Glass RI. Unexpected benefits of rotavirus vaccination in the United States. J Infect Dis. 2011;204:975-977.

7. Patel NC, Hertel PM, Estes MK, et al. Vaccine-acquired rotavirus in infants with severe combined immunodeficiency. N Engl J Med. 2010;362:314-319. 8. Payne DC, Edwards KM, Bowen MD, et al. Sibling transmission of vaccinederived rotavirus (RotaTeq) associated with rotavirus gastroenteritis. Pediatrics. 2010;125:e438-41. 
9. Rasanen S, Lappalainen S, Halkosalo A, et al. Rotavirus gastroenteritis in Finnish children in $2006-2008$, at the introduction of rotavirus vaccination. Scand J Infect Dis. 2011;43:58-63.

10. Iturriza-Gomara M, Wong C, Blome S, et al. Rotavirus subgroup characterisation by restriction endonuclease digestion of a cDNA fragment of the VP6 gene. J Virol Methods. 2002;105:99-103.

11. Blazevic V, Lappalainen S, Nurminen K, et al. Norovirus VLPs and rotavirus VP6 protein as combined vaccine for childhood gastroenteritis. Vaccine. 2011;29:8126-8133.

12. Puustinen L, Blazevic V, Salminen M, et al. Noroviruses as a major cause of acute gastroenteritis in children in Finland 2009-2010. Scand J Infect Dis. 2011;43:804-808.

13. Risku M, Lappalainen S, Räsänen S, et al. Detection of human coronaviruses in children with acute gastroenteritis. J Clin Virol. 2010;48:27-30.

14. Gray J, Vesikari T, Van Damme P, et al. Rotavirus. J Pediatr Gastroenterol Nutr. 2008;46 Suppl 2:S24-31.

15. Lundgren O, Svensson L. Pathogenesis of rotavirus diarrhea. Microbes Infect. 2001;3:1145-1156.

16. Clark HF, Bernstein DI, Dennehy PH, et al. Safety, efficacy, and immunogenicity of a live, quadrivalent human-bovine reassortant rotavirus vaccine in healthy infants. J Pediatr. 2004;144:184-190.

17. Anderson EJ. Rotavirus vaccines: viral shedding and risk of transmission. Lancet Infect Dis. 2008;8:642-649. 
18. Chan J, Nirwati H, Triasih R, et al. Maternal antibodies to rotavirus: could they interfere with live rotavirus vaccines in developing countries? Vaccine. 2011;29:1242-1247.

19. Clark HF, Marcello AE, Lawley D, et al. Unexpectedly high burden of rotavirus gastroenteritis in very young infants. BMC Pediatr. 2010;10:40. 20. Yen C, Jakob K, Esona MD, et al. Detection of fecal shedding of rotavirus vaccine in infants following their first dose of pentavalent rotavirus vaccine. Vaccine. 2011;29:4151-4155.

21. Smith CK, McNeal MM, Meyer NR, et al. Rotavirus shedding in premature infants following first immunization. Vaccine. 2011;29:8141-8146.

22. Vesikari T, Clark HF, Offit PA, et al. Effects of the potency and composition of the multivalent human-bovine (WC3) reassortant rotavirus vaccine on efficacy, safety and immunogenicity in healthy infants. Vaccine. 2006;24:4821-4829. 